\title{
Spring Characterization Methods \& Springshed Mapping
}

\author{
Scott C. Alexander ${ }^{1}$, Andrew J. Luhmann ${ }^{1}$, \\ E. Calvin Alexander, Jr. ${ }^{1}$, Jeffrey A. Green ${ }^{2}$ and Andrew J. Peters ${ }^{2}$ \\ ${ }^{1}$ Geology \& Geophysics Department, University of Minnesota, 310 Pillsbury Dr. SE., Minneapolis, MN \\ 55455; phone (612) 624-3517; email: alexa017@umn.edu \\ ${ }^{2}$ Minnesota Department of Natural Resources, Division of Waters, 2300 Silver Creek Road NE, Rochester, \\ MN 55906.
}

ABSTRACT: Southeastern Minnesota's karst lands support numerous trout streams created by coldwater springs emanating from Paleozoic bedrock. While trout streams have been traditionally managed as surface water resources they are fundamentally supported by clear, relatively constant temperature groundwater. In karst areas this groundwater resource is as vulnerable as surface waters to human activities. Designing Best Management Practices (BMPs) to protect groundwater fed springs should improve the overall protection of Minnesota's trout streams. Dye tracing has been the tool of choice for mapping the recharge area or groundwater basin that feed a particular spring. These karst groundwater basins have been termed "springsheds". In order to accelerate springshed mapping, a two-year study was funded by the Minnesota Environment and Natural Resources Trust Fund as recommended by the Legislative-Citizen Commission on Minnesota Resources (LCCMR). To improve the effectiveness of dye tracing we are applying a variety of new tools to increase our knowledge of the underlying karst systems

Techniques being investigated include temperature and discharge monitoring, detailed structural mapping of the aquifers, unit hydrographs, chemical and isotopic studies. These new methods to define the size and geometry of springsheds can be tested against basins previously defined by dye tracing. In previously untraced basins these predictive tools can be used to design more efficient tracing programs. The following paper demonstrates the application of structural mapping to dye tracing.

\section{INTRODUCTION}

Trout streams depend on a steady supply of clean, cool and constant temperature water to exist. Water management associated with the increasing human impacts of intensive agriculture, new water demands, climate change, and landscape alteration requires more efficient means of defining the springsheds that support and define trout fisheries. Over the past three decades twenty-four springsheds have been defined which feed just twelve of the 173 designated trout streams in Southeastern Minnesota. Additional large groundwater withdrawals for energy production and other development loom in the 
future. Delineation of the recharge areas or springsheds of the trout springs is a crucial first step in the protection of the trout fisheries and the restoration of those that have been degraded.
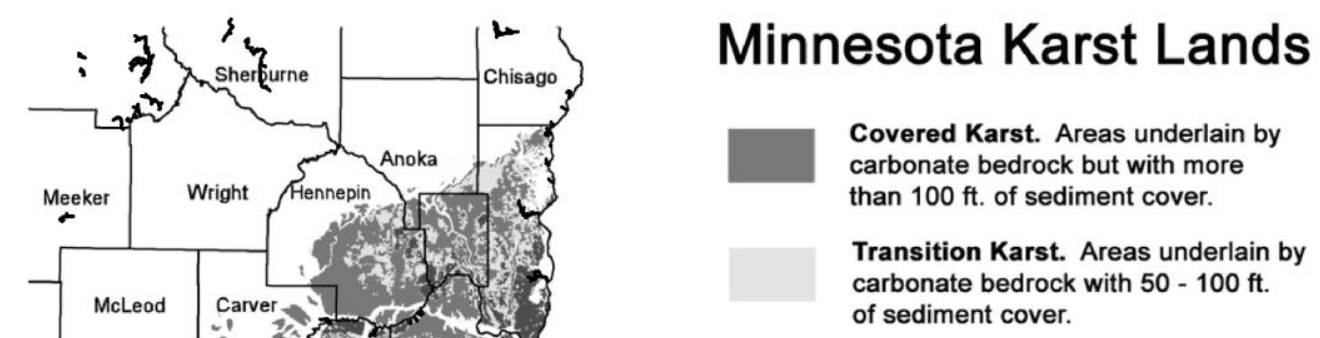

of sediment cover.
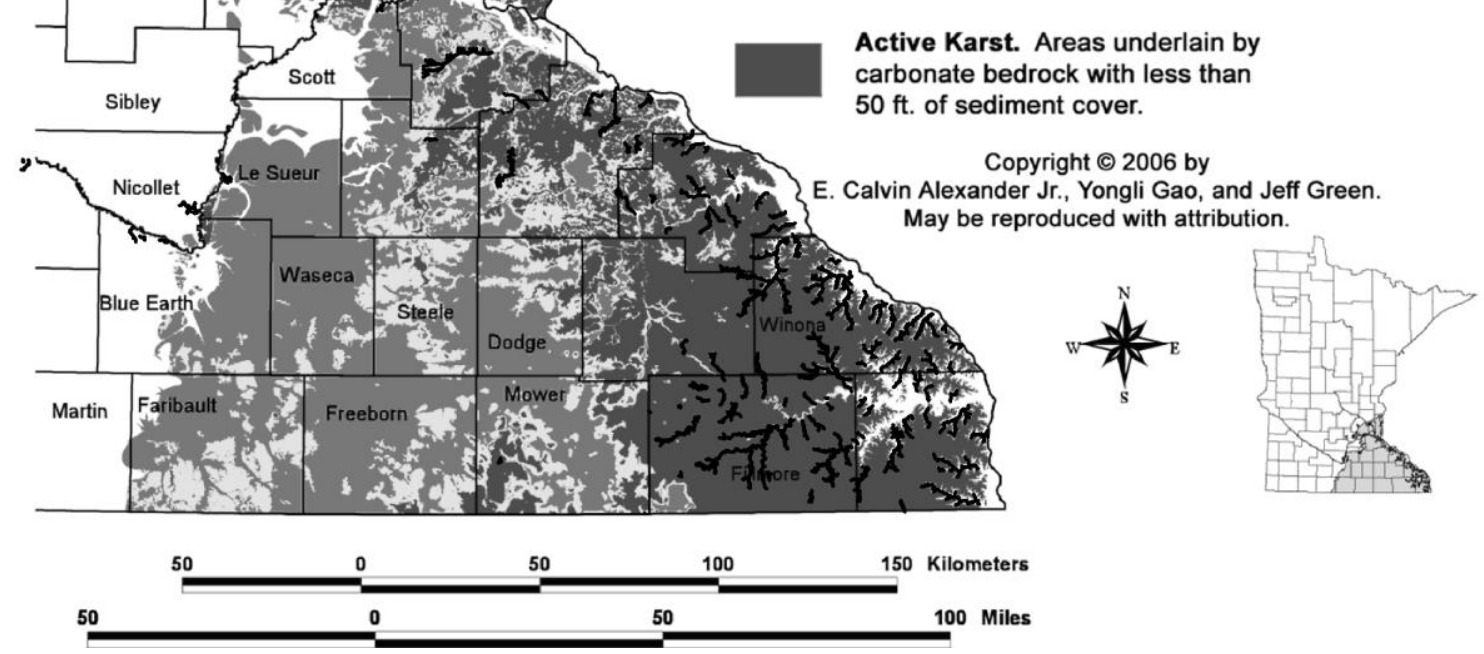

Fig. 1. Minnesota Karst Lands with designated trout streams (heavy lines).

Paleozoic bedrock aquifer systems serve as the primary water supply source for southeast Minnesota trout stream springs. The primary tool for delineating springsheds in Minnesota has been dye tracing (Alexander, 2005, Hötzl, 1998 and Ozark Underground Laboratory, 2002). Despite the use of multiple tracers, dye tracing is time and labor intensive. Most of these trout stream springshed delineation efforts have been conducted in the upper Ordovician Galena limestone (Alexander et al., 1995 and Green et al., 2005). Numerous major springs and related trout streams emanate from throughout the Ordovician and Cambrian aquifer systems. The hydrology of the lower Ordovician and Cambrian springs has been studied only to a limited extent despite their importance for trout streams and relationship to municipal water supply wells (Runkel et al., 2003). See Green et al. in this proceedings volume for a report of initial dye tracing efforts in this part of the section.

Significant work on the hydrostratigraphy of the bedrock underlying southeastern Minnesota is reported in Runkel et al. 2003. Beyond traditional lithographic and chronologic based stratigraphic methods, hydrostratigraphy encompasses lithologically controlled primary permeability as well as secondary fracture and solution enhanced permeabilities. 


\section{GALENA KARST SYSTEM}

One promising technique to improve springshed delineation combines gamma logs of a few water wells with conventional driller's logs to construct detailed structural contour maps. Groundwater flow in karst regions is generally independent of surface topography, but is largely influenced by underlying geological formations and structures (Goldscheider and Andreo, 2007). Conduits present in Southeastern Minnesota karst systems generally run parallel to the local, sub-horizontal bedding planes, and multiple joint systems enable water to move down-dip within and along local bedrock units (Runkel et al., 2003). Therefore, in these relatively flat lying strata, structural contour maps of underlying rock formations may allow the prediction of groundwater flow direction. The working hypothesis is that this method will work best with upper aquifer systems of Southeastern Minnesota that are well above base-level rivers. The corollary hypothesis would be that structural control on groundwater flow direction is less significant when dealing with aquifers at greater depths or with greater saturated aquifer thickness.

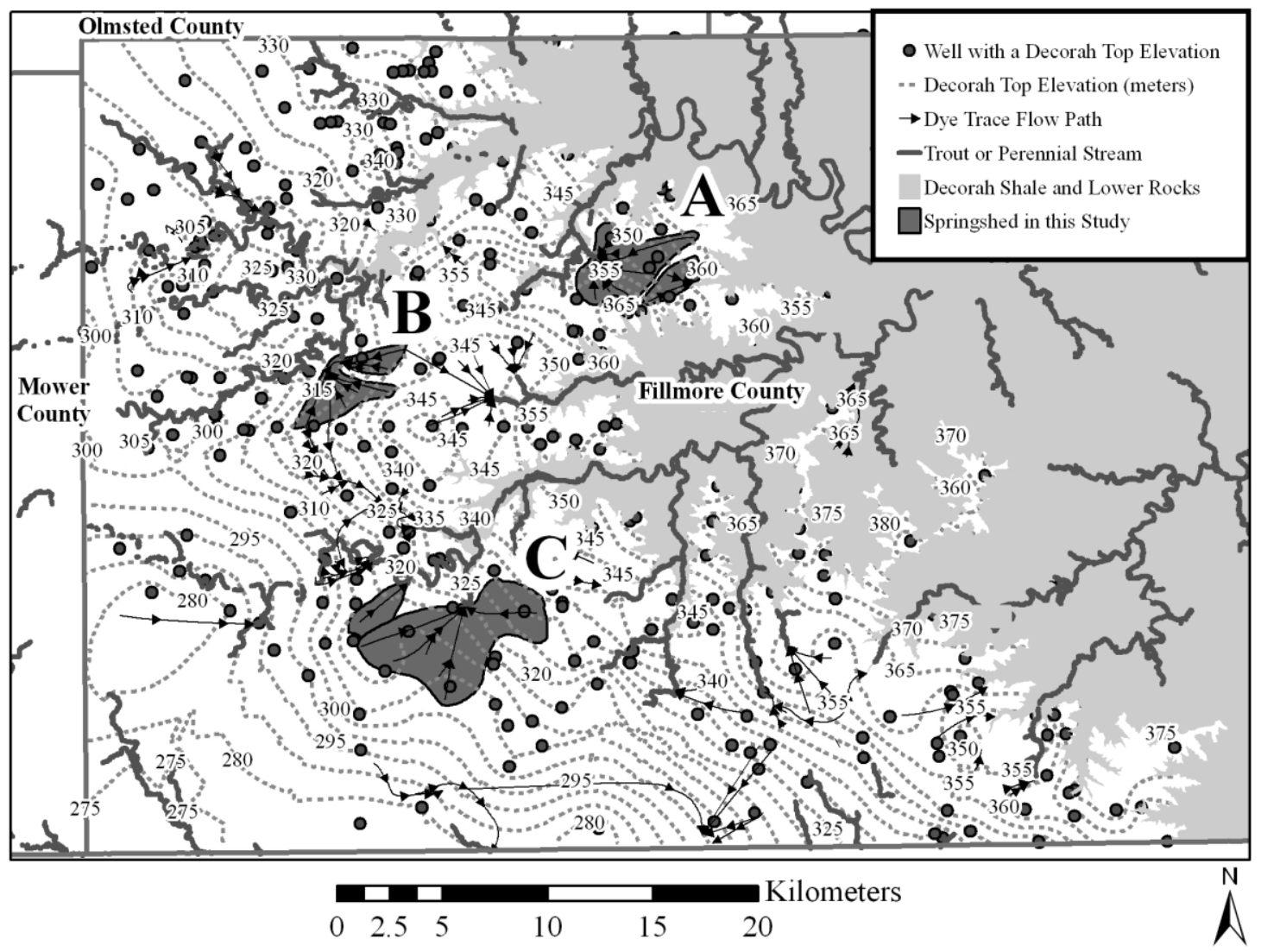

Fig. 2. Structural contours of the top of the Decorah Shale for Fillmore County, Minnesota with groundwater flow paths as defined by dye tracing. Highlighted springsheds "A" are Fountain and Mahoney (Fig. 4), "B" are Waterhole and Wykoff springsheds (Fig. 5), and " $C$ " are Starless River and Cold Spring springsheds (Fig. 6). 
Fig. 3. Stratigraphic column for southeastern Minnesota with representative natural gamma log (after Mossler, 2008).

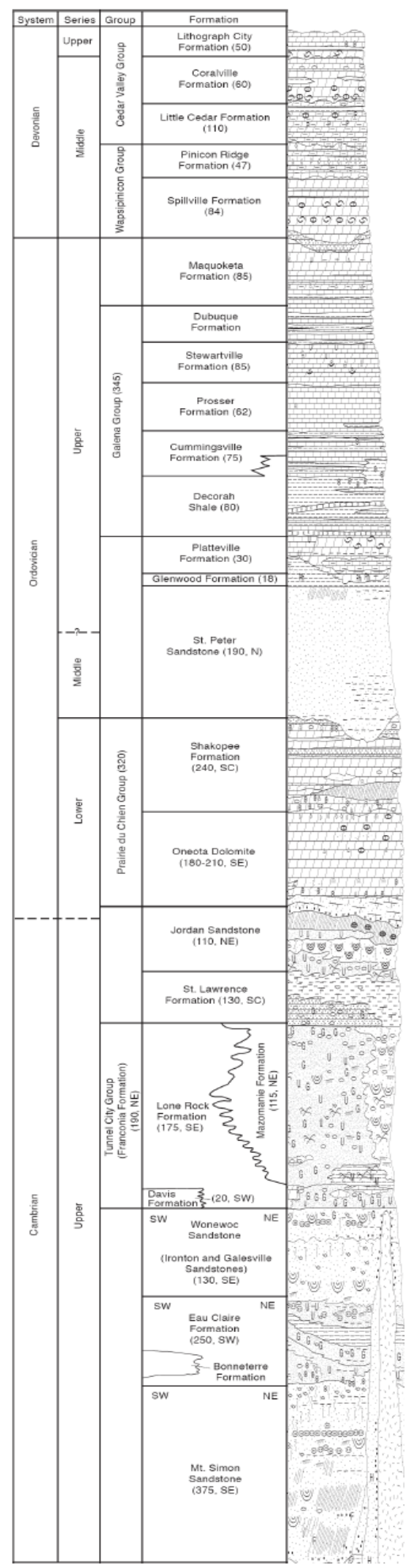

To investigate the application of structural mapping in dye trace interpretation we started our investigation in the Minnesota County with the richest record of dye tracing. Figure 2 portrays the Decorah shale top elevation across Fillmore County, Minnesota. The Decorah shale is a regionally important aquitard that separates the two major Ordovician carbonate systems in Minnesota. The upper aquifer includes the Maquoketa, Dubuque and Galena as depicted in Figure 3. The lower major carbonate unit is the Prairie du Chien formation which is bounded by the St. Peter and Jordan sandstones.

The Minnesota County Well Index (CWI) contains driller's records for water wells throughout Minnesota and is maintained by the Minnesota Department of Health. Over 2,500 CWI records from Fillmore County were compared with fifteen gamma logs recorded by the Minnesota Geological Survey. Gamma logs record the emission of natural gamma radiation produced primarily from potassium (K) in minerals. Shales are often rich in $\mathrm{K}$-feldspar minerals while quartz sandstones have almost no potassium (Runkel et al., 2003). In Figure 3 increasing gamma radiation, and correlated shale content, is depicted on the right side of the figure. Higher potassium produces a stronger signal shifting the natural gamma signal to the right. Representative stratigraphic thicknesses for individual units within a given area were determined from gamma log records.

This detailed stratigraphic information was then used to interpret CWI well logs in greater detail than based on driller's records alone. In particular, the top of the Decorah shale is a gradational contact with the Galena Group. The lowermost member of the Galena is the Cummingville formation which is composed of shales 
interbedded with carbonates. The top of the Decorah is therefore very difficult for well drillers to consistently pick and record. However, the Cummingsville/Decorah contact shows up clearly on gamma logs where continuous shales are observed. Drillers, however, are very adept at identifying the Glenwood/St. Peter contact where they drill through shale into clean sandstone. By adding the thickness of Glenwood, Platteville and Decorah to the Glenwood/St. Peter elevation we can determine the top of Decorah elevation for the selected well.

Determinations of the Decorah Shale top elevation for 264 wells in Fillmore County are represented by the dots in Figure 2. The contours were generated by inverse distance weighted interpolation in $\operatorname{ArcMap}^{\mathrm{TM}}$, v. 9.1. The groundwater flow path lines are from dye traces conducted over the past thirty years (Alexander et al., 1995).

\section{STRUCTURALLY CONTROLLED SPRINGSHEDS}

Two Fillmore County study areas exhibiting structural control of groundwater movement in the upper carbonate aquifer are used as an example of the structural method. The Fountain and Mahoney Springsheds of north-central Fillmore County are shown in Figure 4. In this portion of Fillmore County the Galena formation is found high on ridges separated by deeply entrenched bedrock valleys. The valley floors cut well into the Prairie du Chien and Jordan formations. This creates aquifers with thin saturated thickness near the bottom of the Galena. The boundaries of the springsheds were drawn based on past dye traces.

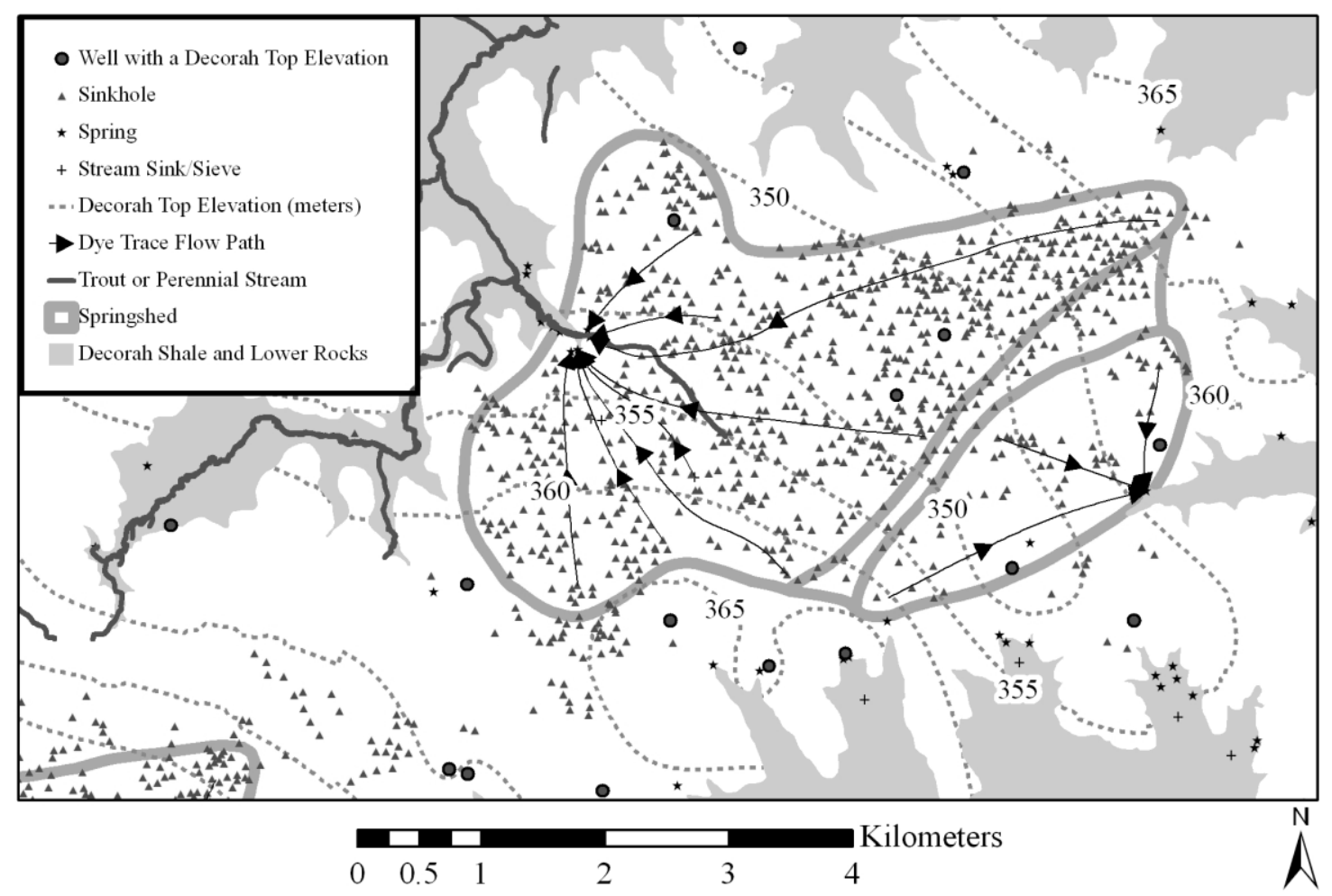

Fig. 4. Fountain (west) and Mahoney (east) springsheds. 
Flow paths and springshed boundaries appear to follow structural controls within the rock formations for these basins. In the Fountain springshed flow originates from a structural high on the south side of the basin at 365 meters flowing north and west to a discharge point at Fountain Big Springs. However the northern portion of the Fountain basin appears to flow up dip to the same springs. This anomaly may be due to the groundwater flow paths in Galena systems which typically follow high gradient paths initially (including free fall waterfalls) to lower level, very low gradient paths that terminate in springs just above the Decorah Shale. Alternatively, the density of data points constraining the structural mapping is low suggesting that flow on the subspringshed scale may be controlled by small scale structural features. This knowledge then enables us to extend springshed boundaries and to better design future dye traces in adjacent basins.

A second example of structural control can be found a few miles west of Fountain near the town of Wykoff (Figure 5). The Waterhole and Wykoff springsheds show perhaps an even stronger structural control. Water in both basins flows from a structural high of about 340 meters in the Eastern portion of Figure 5 towards Mahoods Valley. Large springs found on the west side of Mahoods Valley are fed by the Waterhole springshed to the South. Springs on the East side of Mahoods Valley capture water from the Wykoff springshed to the East.

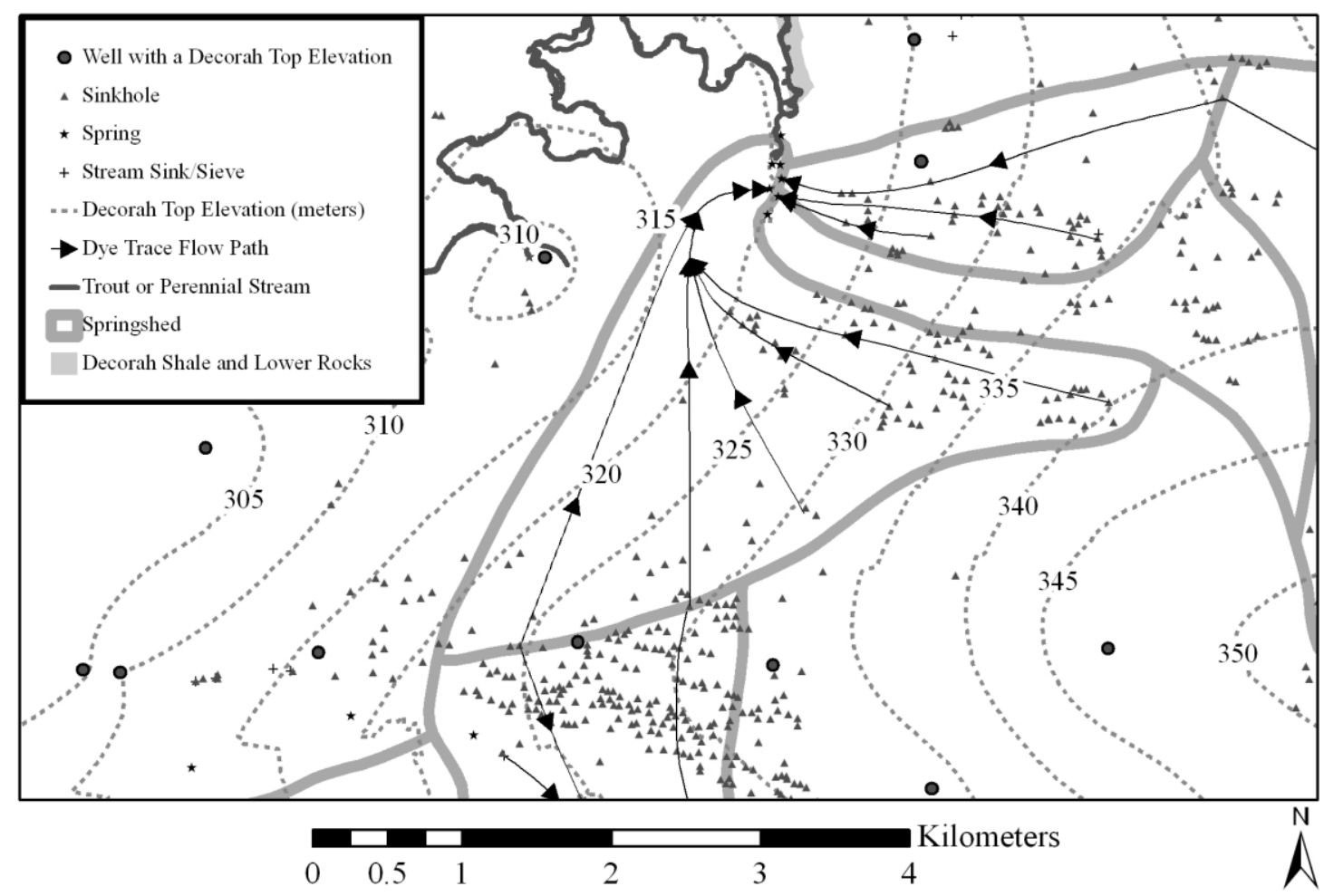

Fig. 5. Waterhole (center) and Wykoff (northeast) Springsheds.

While there is generally good agreement of dye trace vectors with structural control there are some discrepancies. In particular, as flow approaches the west side of Mahoods Valley in the Waterhole springshed it makes sharp turn to the east flowing apparently up dip. Since the bottom of Mahoods Valley cuts into the Decorah shale aquitard we know the springs on the west side of the valley have to make a loop to the south. A simple 
explanation may be found in the density of data used to construct the structural contours. Note the round circles in Figure 5 which denote wells that had top of Decorah elevation. While there are eight wells within Figure 5 none of them are immediately in Mahoods Valley. Additional, detailed mapping of surface outcrops in Mahoods Valley could be used to add additional structural information.

\section{HYDRAULICALLY CONTROLLED SPRINGSHEDS}

The Cold Spring and Starless River springsheds of southwestern Fillmore County are shown in Figure 6. The larger Starless River springshed flows to the northeast almost perfectly against the structural dip. Similarly the smaller Cold Spring springshed flows up dip. In this southwest area of Fillmore County the regional base-level river, the Root River, is not incised through the Galena Formation creating thicker saturated aquifer conditions in the Galena. Thick saturated conditions may reduce the sensitivity of groundwater flow to underlying bedrock structures. The flow paths are therefore more dependent on the regional water table than on subsurface structures. Both the structurally controlled and hydraulically controlled Galena springsheds typically yield groundwater flow velocities of kilometers per day and dye pulses that are a few hours to a day wide with a small but characteristic exponential tail.

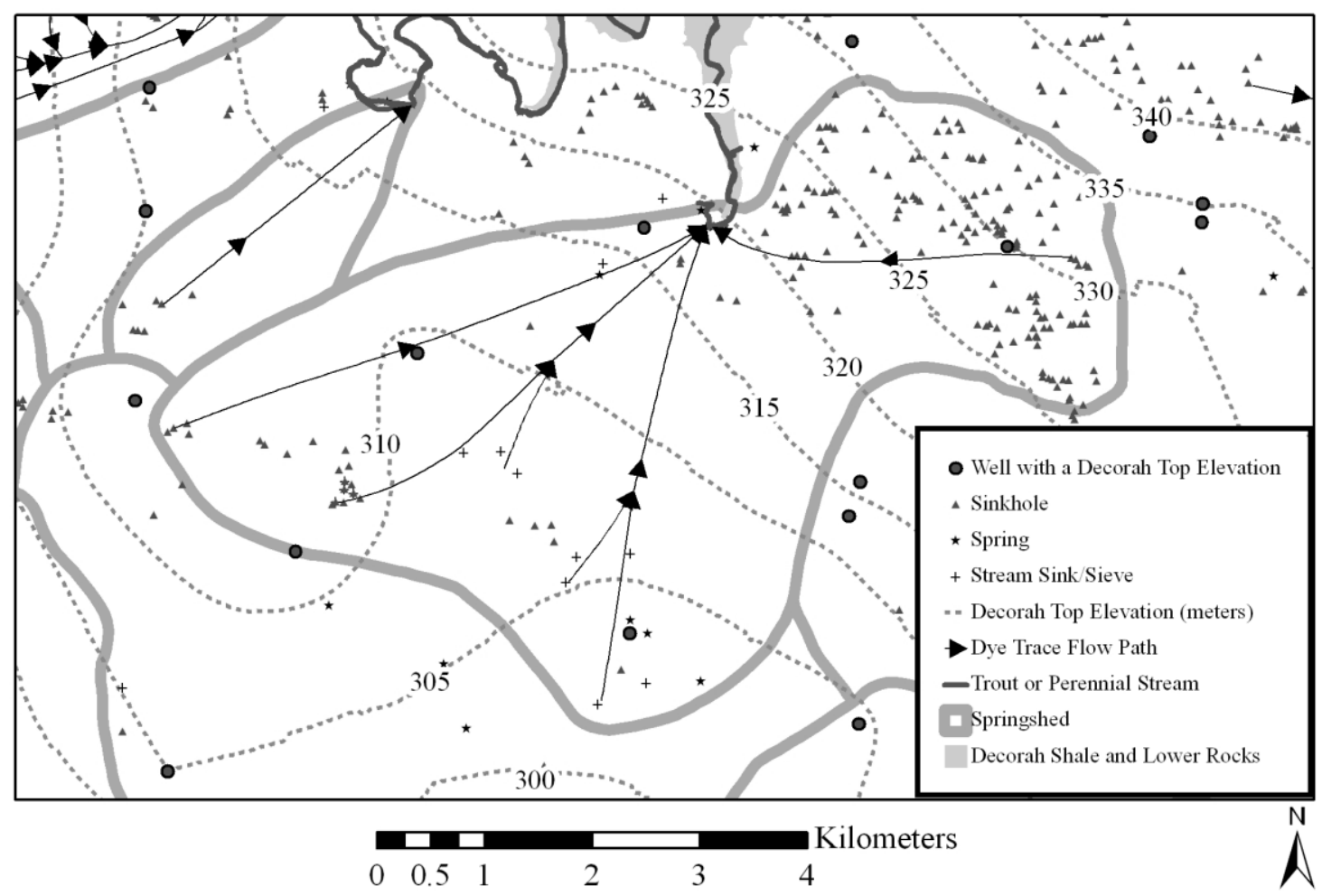

Fig. 6. Starless River and Cold Spring hydraulically controlled springsheds.

\section{FUTURE WORK}

Of the hundreds of Minnesota dye traces conducted over the last thirty years only six, including a new trace by Green et al. (in this proceedings volume), have been conducted in the Lower Ordovician/Upper Cambrian Aquifer system. This lower portion of the 
stratigraphic section exhibits distinctly fewer surficial karst features than the Galena Karst. However, the lower aquifer feeds significantly more trout streams, and several fish hatcheries. The lower aquifer is hydrologically more complex than the Galena since it encompasses interbedded sequences of coarse clastics (sandstones), fine clastics (shales) and carbonates while the Galena lacks coarse clastics (Runkel et al., 2003).

The logistics of dye tracing in these stratigraphically lower units and the resulting dye breakthrough curves are more complex. The leading edges of the dye pulses have been observed to travel with speeds ranging from kilometers per day to kilometers per year. The dye pulses are complex, often weeks to months wide, often contain multiple peaks and some respond to recharge events with repeated dye pulses.

Dye tracing becomes logistically more difficult as transit times of kilometers per day in the Galena increase to kilometers per year in the Prairie du Chien. The result is that it will be difficult to conduct hundreds of dye traces in the Lower Aquifer System. Future dye tracing efforts in this part of the geologic section will have to be conducted with significantly more planning and forethought. Individual tracing dyes may take years to flush out of the aquifer system severely limiting the number of dye traces that can be conducted in a given area to number of different tracing materials available. By applying supplemental geologic and hydrologic tools dye traces can be conducted more efficiently and be better designed to answer relevant questions on the first dye tracing attempt.

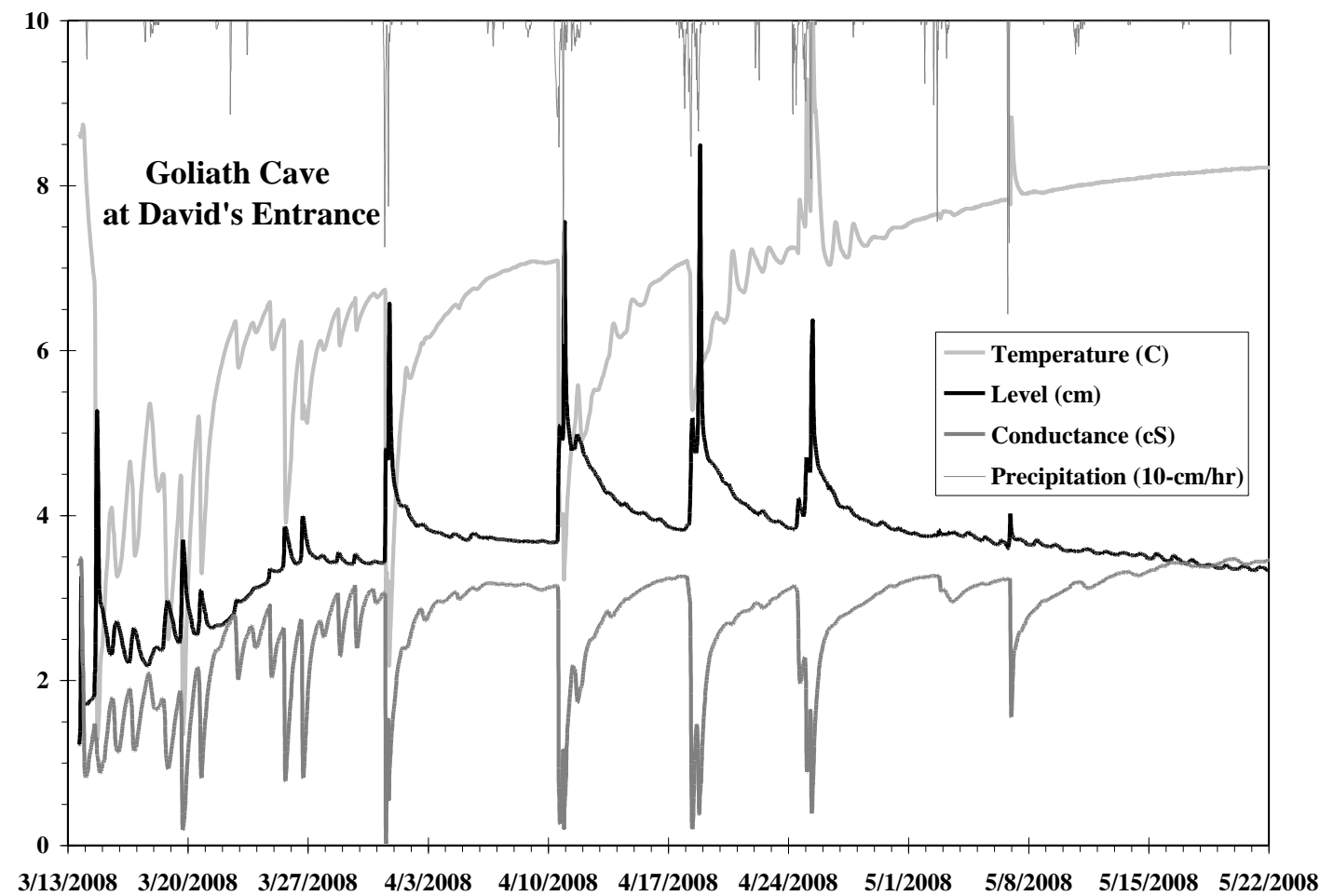

Fig. 7. Stream hydrograph (black line) from Goliath Cave, Minnesota with temperature (light gray), conductance (dark gray) and precipitation (thin gray).

Additional tools beyond structural mapping include temperature and conductivity monitoring in addition to traditional hydrographs. High resolution measurements, at the scale of minutes or seconds, allow separation of the hydrograph. Figure 7 is a hydrograph 
from a conduit passage in Goliath Cave, Minnesota. The spring snowmelt started in midMarch with a daily freeze thaw cycle that produces a strong daily signal in temperature, conductance and water level. Spring rain storms generate spike inputs with normal recession curves. As plant growth begins to pick up a small scale sinusoidal fluctuation appears in early May. Each of these three hydrologic effects provide information on the connectivity and rate of movement between surficial and soil waters as they recharge the groundwater system. Estimated recharge rates combined with total spring discharge can also be used to estimate basin area (Peters et al., 2006). The estimated basin area can then be compared to structural mapping to help define springsheds which can then be tested by dye tracing.

\section{SUMMARY}

Previous studies of southeastern Minnesota Karst had focused almost entirely on dye tracing. While an invaluable tool for springshed delineation, dye tracing alone cannot be extended across the area of interest in a timely fashion. As pressures on our natural resources, including trout streams, have grown exponentially our knowledge of how to protect these resources have grown only at a slow linear pace.

The results presented here for the Galena karst system leverage existing dye trace data with water well driller's records and down hole gamma logging. The combination of these tools should lead to a better understanding of the overall flow system and greatly facilitate future dye tracing efforts in the Galena karst.

Springs originating from Lower Aquifer System including the St. Peter, Prairie du Chien, Jordan and St. Lawrence are a much less understood but even more important resource with regard to trout streams. At only six dye traces to date we are many years behind efforts in the overlying Galena Karst. Tools and techniques that we have used to define the Galena Karst system can be extended to the Lower Aquifer System, hopefully greatly accelerating the pace of springshed delineation.

\section{ACKNOWLEDGEMENTS}

Funding for this project was provided by Minnesota Environment and Natural Resources Trust Fund as recommended by the Legislative-Citizen Commission on Minnesota Resources (LCCMR) and the Minnesota Department of Natural Resources Division of Waters.

\section{REFERENCES}

Alexander, E.C., Jr., J.A. Green., S.C. Alexander and R.C. Spong (1995) "Springsheds". Plate 9 in Geological Atlas of Fillmore County, Minnesota, County Atlas Series, Atlas $C-8$, Part B, Minnesota Dept. of Natural Resources, St. Paul.

Alexander, S.C. (2005) Spectral Deconvolution and Quantification of Natural Organic Material and Fluorescent Tracer Dyes" in Geotechnical Special Publication No. 144, Sinkholes and the Engineering and Environmental Impacts of Karst, Proceedings of the Tenth Multidisciplinary Conference, pages 441-448. 
Goldscheider, N., and B. Andreo (2007) "The Geological and Geomorphological Framework," pages 9-23, in Methods in Karst Hydrogeology, Goldscheider, N., and D. Drew, eds., Leiden, Netherlands: Taylor \& Francis/Balkema, 264 pages.

Green, J.A., S.C. Alexander and E.C. Alexander Jr., (2005) "Springshed Mapping in Support of Watershed Management" in Geotechnical Special Publication No. 144, Sinkholes and the Engineering and Environmental Impacts of Karst, Proceedings of the Tenth Multidisciplinary Conference, pages 403-409.

Hötzl, H. (1998) "Karst Groundwater" pages 398-437, in Tracing Technique in Geohydrology, W. Käss (editor), Rotterdam, NetherlandsL: A.A. Balkema, 581 p.

Mossler, J.H. (2008) "Paleozoic stratigraphic nomenclature for Minnesota" Minnesota Geological Survey Report of Investigations 65, 76 pages, 1 plate.

Ozark Underground Laboratory (2002) "Ozark Underground Laboratory's Groundwater Tracing Handbook", Protem, MO: Ozark Underground Laboratory, 35 pages.

Peters, N.E., J.B. Shanley, B.T. Aulenbach, R.M. Webb, D.H. Campbell, R. Hunt, M.C. Larsen, R.F. Stallard, J. Troester \& J.F. Walker (2006) "Water and Solute Mass Balance of Five Small, Relatively Undisturbed Watersheds in the U.S.", Science of the Total Environment, 358:221-242.

Runkel, A.C., R.G. Tipping, E.C. Alexander Jr., J.A. Green, J.H. Mossler and S.C. Alexander (2003) "Hydrogeology of the Paleozoic Bedrock in Southeastern Minnesota", Minnesota Geological Survey Report of Investigations 61, 105 pages, 2 plates. 